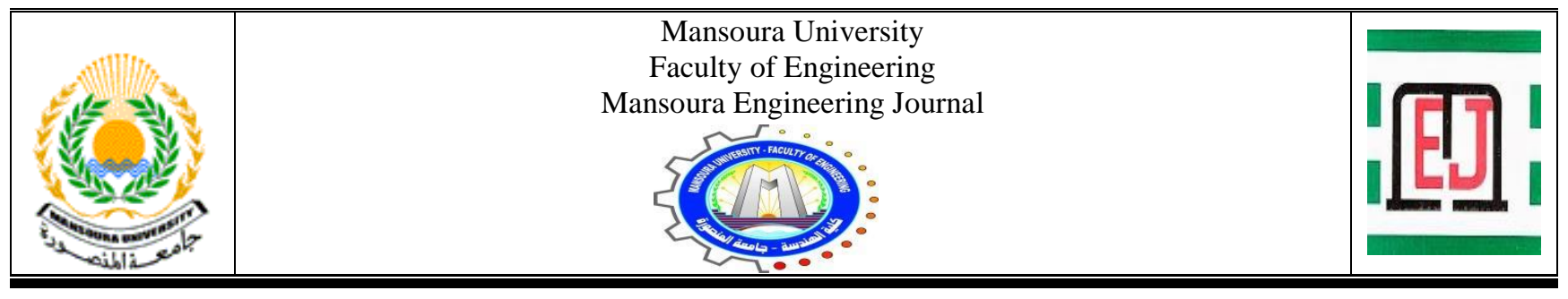

\title{
Influence of Misalignment Method on Performance of Dowel Bars in Joints of Rigid Pavement
}

\author{
Mostafa M. Rabah, Mohammed S. Eisa and Ahmed T. Elghanam*
}

\begin{tabular}{|l|}
\hline KEYWORDS: \\
Rigid pavement. \\
JPCP. \\
Dowel bar. \\
Transverser joint. \\
Misalignment \\
Load-strain \\
relationship. \\
Cracking load. \\
Ultimate load \\
\\
\\
\end{tabular}

Abstract - Load transfer across transverse joints has always been into consideration of rigid pavement design. Steel dowels of circular cross-section were the standard load transfer device. Many problems have been related to steel dowels such as corrosion. At the same time, joints are also damaged by repeated loading over time.

This research presents an experimental investigation into the comparison between the Glass Fiber Reinforced Polymer (GFRP) and steel dowel bars placed in the transverse joints of the Jointed Plain Concrete Pavement (JPCP). The main objective of this study to assess the suitability of using GFRP dowel bars as an alternative corrosion-free material to conventional steel dowels. This research contains a set of variables and conditions in which we can assess which dowel bars are the best. Among these variables is the type of material the dowel bar is made of, whether it is steel or GFRP, and the misalignment method by which the dowel bar stacks in the transverse joints.

Conclusion: As expected, the use of GFRP dowel bars improved the bearing of the applied loads exposed on the specimens compared to their counterparts of the specimens with steel dowel bars by about $125 \%$. The experimental results showed that using the horizontal misalignment method was a practical and good method to arrange the dowel bars crossing the transverse joints between JPCP slabs.

\section{INTRODUCTION}

I $\mathrm{n}$ rigid pavements, joints are used to regulate cracking caused by thermal and environmental factors. Longitudinal joints are parallel to traffic; transverse joints are perpendicular to traffic. The three types of transverse joints most commonly seen in rigid pavements are contraction joints, construction joints, and extension or isolation joints. The role of contraction and construction joints in regulating crack patterns in rigid pavement is quite similar to separate the slab

Received: (04 June, 2021) - Revised: (22 September, 2021) - Accepted: (26 September, 2021)

Mostafa M. Rabah, Professor of Surveying and Geodesy, Department of Civil Engineering, Benha Faculty of Engineering, Benha University, Egypt. (email:mrabah@bhit.bu.edu.eg) from adjacent structures such as bridge abutments and manholes, expansion and isolation joints are commonly employed.

Dowels are frequently utilized to transfer loads between adjacent slabs also providing vertical and horizontal alignment. Smooth epoxy-coated steel dowels are now used to transfer loads and allow for longitudinal thermal expansion and contraction across the transverse joints. Due to steel expansion during the corrosion process, corrosion of steel dowels causes serious degradation of the rigid pavement. Steel dowel expansion causes considerable pressures in the concrete around

Mohammed S. Eisa, Lecturer, Department of Civil Engineering, Benha Faculty of Engineering, Benha University, Egypt. (e-mail: mohamedeisa524@bhit.bu.edu.eg)

Corresponding Author: Ahmed T. Elghanam, Demonstrator, Department of Civil Engineering, Benha Faculty of Engineering, Benha University, Egypt (e-mail: ahmed.elghanam@bhit.bu.edu.eg) 
the dowel at the joint, preventing joint movement. The freezing or binding of the joint can produce significant stresses in the concrete, causing cracking. The load that the joint can transfer is also reduced as a result of these stresses. Epoxy-coated steel dowels are used to decrease the effects of deicing salts on dowels. The thin layer of epoxy is only effective if the coating is free of nicks, cracks, and other abrasions. Coated dowels must be handled and stored with care throughout construction procedures. Small defects in the epoxy covering are unavoidable.

Steel dowel bars are the most conventional type of dowel bars that are used as load transfer devices across the joints of JPCP. Corrosion of these steel bars causes dowel looseness (DL) due to the formation of a non-uniform flaky coating surrounding the dowel bar and freezing of the dowel (Mancio et al. 2008) [1]. As a result, high bearing stress is induced in the concrete surrounding the dowels owing to repeated traffic loads. The expansion and freezing of steel dowels due to corrosion increases surface irregularities and generates a substantial number of locked-up stresses. Pavements deteriorate rapidly as a result of the combined impacts of the above problems. On the other hand, GFRP dowel bars are made of a corrosion-proof material. Their surface is highly smooth and unlike steel; they do not require greasing to lower the bond with concrete. The slab movements are less restricted due to the minimal bond that exists between the GFRP bars and concrete, there are substantially less locked-up stresses. Although GFRP dowels are approximately $50 \%$ higher in cost than steel dowels, the total expense of their maintenance over the long term, their transportation costs and the cost of installation are less (Bian 2009) [2]. Therefore, they can be a practical alternative to epoxy-coated steel dowels.

Many studies have been conducted to address the pavement distresses and improve the performance of JPCP over its service life. These improvements involve the investigation of various materials and shapes as alternatives to the conventional rounded steel dowel bars. Although alternative shapes such as the elliptical dowel bar may improve the Load Transfer Efficiency (LTE) and reduce the bearing stress on the concrete surrounding the dowel bars (Porter et al. 2006) [3]. The corrosion of dowel bars remains a crucial problem. Eddie et al. (2001) [4] conducted experimental investigations and a field evaluation into the performance of $38 \mathrm{~mm}$ diameter GFRP dowels compared to $32 \mathrm{~mm}$ epoxy-coated steel dowel bars. The experimental program involved three phases. Phase one involved a static load test for slabs resting on a weak subgrade which was represented by steel springs with a stiffness of 3.6 $\mathrm{MN} / \mathrm{m}^{3}$. Phase two involved replacing the weak subgrade with a stiff subgrade of $300 \mathrm{~mm}$ thick compacted limestone with stiffness of $133.3 \mathrm{MN} / \mathrm{m}^{3}$. Phase three involved applying a cyclic load varying between 20-130 kN and at a frequency of 6 $\mathrm{Hz}$ until a total of 1 million load cycles was reached. The results of the static and cyclic tests revealed that the $38 \mathrm{~mm}$ GFRP dowel bars have a comparable response to that of the $32 \mathrm{~mm}$ diameter epoxy-coated steel dowels. A field evaluation for GFRP dowels in an actual pavement was undertaken 8 months after its construction using FWD. The results showed that the LTE for the $38 \mathrm{~mm}$ GFRP dowel bars was almost the same as $32 \mathrm{~mm}$ diameter epoxy-coated steel dowel bars.
Porter and Pierson (2007) [5] carried out experimental tests on six highway dowel types of various materials (steel, stainless steel and GFRP), different shapes (round and elliptical), different sizes and different joint widths $(0,3.2 \mathrm{~mm}$ and 12.7 $\mathrm{mm})$. The experiments were conducted using the modified AASHTO T253 test (Porter et al. 2001) [6] which is a modified test of the original AASHTO T253 test to determine the modulus of dowel support, ko (AASHTO 1993) [7]. Strain gauges were placed on the embedded length of some of tested bars to show the bending moment of the dowel bars. The measured data were compared with the theoretical model of Friberg (1940) [8] for a dowel bar of semi-infinite length supported on an elastic foundation. The results showed that for similar dowel sizes, GFRP dowels produced more deflection than steel dowels. Also, elliptical-shaped dowels reduced the dowel bearing stress as compared with rounded-shaped ones. However, the results showed that for all dowel types and shapes, a $22.25 \mathrm{kN}$ load can be transferred by each of these dowels before reaching the allowable stress as determined by the American Concrete Institute (ACI) Committee 325 (1956) [9]. It was observed that the measured bending strain was lower than that estimated by the Timoshenko model (Timoshenko and Lessels 1925) [10]. These tests did not incorporate a cyclic load test to assess the long-term performance of elliptical and GFRP dowels.

Robert et al. (2010) [11] conducted a physical, mechanical and durability evaluation of GFRP dowels in terms of their usage as dowel bars in JPCP. The investigation involved two types of matrix materials namely vinlyester and polyester. The durability of the GFRP dowels based on each of these matrix materials was evaluated by testing embedded GFRP dowels in concrete while being immersed in water at a temperature of 60 ${ }^{\circ} \mathrm{C}$ for 75 days to replicate the aging process. Shear strength and flexural modulus were compared with reference un-aged samples. The results indicated that the GFRP dowels based on a vinlyester matrix have a higher shear strength and flexural modulus than those based on a polyester matrix. It also showed that the aging process produced an insignificant effect on the shear strength and the flexural modulus of GFRP dowels for both matrix types; consequently, a good long-term performance can be expected for GFRP dowels in JPCP.

Al-Humeidawi et al. (2018) [12] used epoxy-coated steel and GFRP dowels supported on a base system with similar stiffness to a real pavement system. An experimental program was undertaken to evaluate dowel misalignment and joint lockup. The study looked at the impacts of dowel misalignment and cyclic traffic wheel load on LTE, relative deflection, and dowel looseness for epoxy-coated steel and GFRP dowels. When GFRP dowels are used instead of epoxy-coated steel dowel bars for severe joint opening, the load required for joint opening is considerably decreased.

Since pavements expand and contract continuously during their service life, the concrete surrounding steel dowels may deteriorate more quickly than the concrete surrounding GFRP dowels. When there is a dowel misalignment, this degradation accelerates and can lead to failure like the one seen in specimen GH2N4. Even though the experimental findings clearly showed that GFRP dowels perform better under test conditions. However, more experimental data is required for a comprehensive quantitative assessment. Despite the restrictions 
mentioned above, it was encouraging to see that the overall trend of the specimens.

Material characteristics of concrete such as compressive strength, modulus of elasticity, and flexural strength are key input parameters in the concrete pavement thickness design. The modulus of elasticity describes the stiffness of concrete material and can be either determined experimentally or predicted using the 28-day compressive strength of concrete from equation 1, from the ACI Committee 318 (2014) [13].

$$
\mathrm{E}_{\mathrm{c}}=57000 \sqrt{\left(\mathrm{f}^{\prime} \mathrm{c}\right)}
$$

GFRP dowel bars are considered to replace steel dowel bars. Related research work has been conducted to explore the properties of fiber reinforced polymer (FRP) dowel bars (Larralde 1990) [14]. Analyzed the feasibility of utilizing FRP bars in the longitudinal joints of rigid pavements. It was found that in terms of cross-sectional area, the amount required for FRP bars was greater than that for steel bars. This was due to the elastic modulus of FRP was lower than that of steel. In terms of material cost, the least costly FRP alternative, GFRP bars, is approximately $50 \%$ more expensive than epoxy-coated steel bars. On the other hand, avoidance of corrosion-related degradation may be able to extend the joint's service life. Which leads to a longer service life of the pavement. Thus, it is necessary to estimate the effective life of FRP dowel bars considering all failure mechanisms, for use in life cycle cost analysis (LCCA) to compare the overall cost of employing the dowel bars made of these two materials (steel and FRP).

Joint distress is the root cause of many concrete pavement troubles. Dowel looseness and misalignment are two common causes of joint distress. These two occurrences have already been studied separately. Dowel looseness is defined as an expansion of the dowel socket caused by frequent traffic stress, wear, or corrosion of steel bars (Teller and Cashell 1958) [15].

Dowel misalignment occurs when the dowel bars are misaligned in locations and/or orientations during the joint building process. Misaligned dowels restrain slab movement by locking the transverse joints, which can cause mid-span fractures, slab corner breakage, and joint spalling (Tayabji 1986) [16].

The two types of dowel misalignments are: (a) translational misalignments, which occur when the entire dowel bar is offset from the central plane of the concrete slab in any direction (horizontally, vertically, or longitudinally) but while remaining parallel to the centerline of the pavement, as shown in Fig. (1). Skew or rotational misalignments, which occur when the dowel stays in the slab's center plane but tilts horizontally, vertically, or both ways, as shown in Fig. (2) (Khazanovich et al. 2001) [17]. This study focuses on skew misalignments because they create a greater restriction in slab movement and are more harmful than translational misalignments (Prabhu et al. 2006) [18].

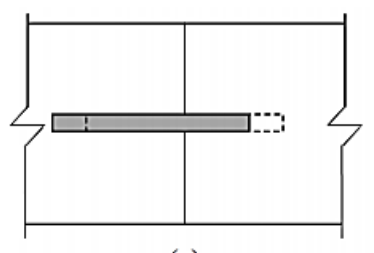

(a)

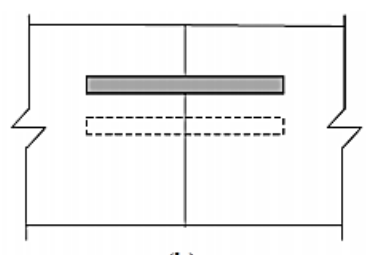

(b)
Fig. (1): Sectional view of JPCP with translation misalignments (a) horizontal; (b)Vertical.

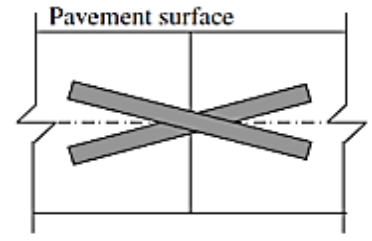

(a)

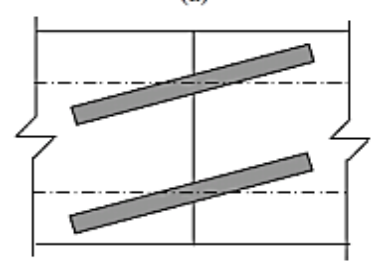

(c)

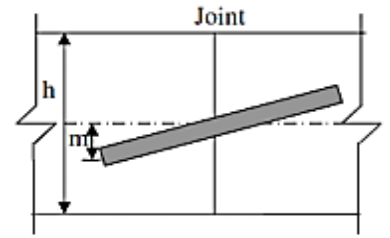

(b)

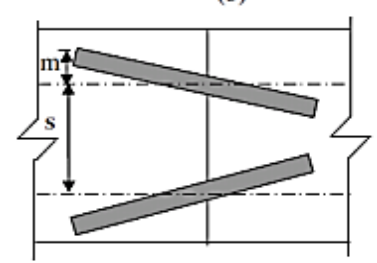

(d)

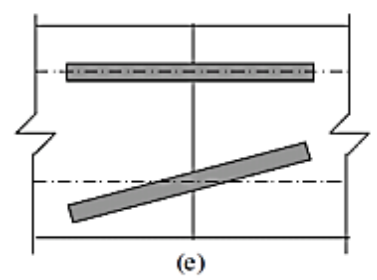

Fig.(2): Various types of dowel misalignment: (a) non-uniform vertical misalignment; (b) uniform vertical misalignment; (c) uniform horizontal misalignment; (d) non-uniform horizontal misalignment; (e) partial horizontal misalignment

Considering the enormous negative impacts on joints and pavement performance, there are just a few studies on the impacts of dowel misalignment. Most previous studies concentrated on determining the amount and types of misalignments that would induce joint distress. Segner and Cobb (1967) [19] examined $1830 \mathrm{~mm}$ wide, $1680 \mathrm{~mm}$ long, and $250 \mathrm{~mm}$ thick concrete pavement sections. In comparison to aligned dowels, the stress needed to open the joint rose substantially when the misalignment magnitude was more than $6.4 \mathrm{~mm}$.

To provide criteria for permissible dowel misalignment, Prabhu et al. [20,21,22] conducted both experimental and numerical studies. One, two, three, and five $32 \mathrm{~mm}$ diameter steel bars with various misalignment magnitudes $(0,6.35,12.7$, 19 , and $25.4 \mathrm{~mm}$ per half-length of the bar) and misalignment methods were used in their research (vertical, horizontal, and combined). The findings revealed that when the stress per dowel surpasses $5-7 \mathrm{kN}$, all joints in a rigid pavement begin to slide. They also discovered that when the degree and nonuniformity of dowel misalignment grows, the joint-opening force per dowel rises.

Recently, Hoegh and Khazanovich (2009) [23,24] conducted experimental and computational studies to investigate the influence of dowel misalignment on LTE. A concrete beam $(457 \times 1200 \times 203 \mathrm{~mm})$ was used in the test, which was equipped with four $38 \mathrm{~mm}$ circular steel bars. Each bar measured $457 \mathrm{~mm}$ in length, with $229 \mathrm{~mm}$ embedded in concrete with various degrees of misalignment. The dowels were sequentially pulled out for $6.4 \mathrm{~mm}$ in the longitudinal direction and the pull-out force versus displacement was 
recorded. By turning the beam on its side and applying direct shear to the non-embedded section of the dowels, the shear capacity of the dowel bar was determined.

As a result, the test setup did not reflect actual slab holes in the field. In addition, casting the specimens in a vertical direction may have decreased the differences in shrinkage stresses for various dowel orientations (J. K. Kim and Lee 1998; Lim et al. 2009) [25,26], which is a significant component in bond strength growth. The test setup eliminated the potential of extra bearing stress coming from the neighboring dowels' restricted mobility. On the other hand, higher misalignment magnitudes resulted in a decreased shear capacity for the dowel bar and greater concrete degradation. In JPCP, GFRP dowels, as non-corrodible dowel bars, can be a suitable alternative to steel dowel bars, particularly in extreme weather circumstances. GFRP dowels as load transfer devices in rigid pavements have been studied in several research (Vijay et al. 2009) [27].

(Silva et al.2021) [28] Explored the impact of dowel bar misalignments on the maximum flexural stresses for the JPCP through numerical modeling with the FEM program Ever FE 2.25. As a result, a typical bus corridor construction was simulated with bars subjected to various misalignment magnitudes and kinds as well as a positive temperature differential. The joint opening impact on the stresses caused by dowel bar misalignment concerning the road authorities' limitations for buildings in tropical climates was also investigated. The influence of base type (cement-treated and asphalt mixture), as well as the bonding conditions between concrete slab and base, were also investigated.

During simulations with the concrete slab bonded to the base layer, misaligned dowel bars did not result in a rise in flexural stresses. Misaligned dowel bars increased flexural stresses by $6.4 \%$ and $13.2 \%$, respectively, for asphalt mix and cement-treated base unbounded to the upper slab, when compared to structures under the same conditions but with properly positioned dowel bars.

The objective of this research was to investigate the behavior of GFRP dowels that are locally fabricated for transverse construction joints of a rigid pavement under the effect of typical loading conditions. The behavior of GFRP dowels is compared to that of steel dowels with a focus on the impact of the dowel bar misalignment method on the pavement slab's performance when applied to loads as well as its effect on the types of dowel bars if they were steel or GFRP. This study uses a scaled model of a rigid pavement section subjected to static loads to test GFRP and steel dowels. A portion of a full-thickness, $200 \mathrm{~mm}$, rigid pavement slab with a limited length and width of $1000 \mathrm{~mm}$ is represented by the scaled model. The study program consisted of testing eight slab specimens. The first 4 slabs were tested under point load conditions by using steel dowels whereas the final 4 slabs were tested under point load conditions by using GFRP dowels. Considered in this program that all slabs during applied the load are placed on 3 layers of soil with a total thickness of $750 \mathrm{~mm}$.

\section{MATERIALS PROPERTIES}

\subsection{Concrete}

Trial mixes were carried out in the reinforced concrete laboratory at the Faculty of Engineering, Benha University. A suitable mix was selected to get a target cubic compressive strength of $250 \mathrm{~kg} / \mathrm{cm}^{2}$ at 28 days. The properties of the materials used to prepare the concrete mix; namely fine aggregate, coarse aggregate, cement, mixing water are explained in Table (1).

TABLE (1)

PROPERTIES OF CONCRETE MIXES.

\begin{tabular}{|c|c|c|c|c|c|c|c|}
\hline \multirow{2}{*}{$\begin{array}{l}z \\
\vdots \\
z\end{array}$} & \multicolumn{4}{|c|}{ Mix proportions. $\mathrm{Kg} / \mathrm{m}^{3}$} & \multirow{2}{*}{$\begin{array}{c}\text { Unit } \\
\text { Weight }\end{array}$} & \multirow{2}{*}{$\begin{array}{l}\text { C.A/ } \\
\text { F.A. }\end{array}$} & \multirow{2}{*}{$\mathrm{W} / \mathrm{C} \%$} \\
\hline & $\mathbf{C}$ & $\mathbf{W}$ & F. A & C.A & & & \\
\hline 1 & 350 & 175 & 630 & 1260 & 2460 & 2 & 50 \\
\hline
\end{tabular}

\subsection{Fine Aggregates}

Natural siliceous sand was used as fine aggregate in the concrete mix. It was clean and almost free from impurities. In the laboratory, a sieve analysis of the fine aggregate was performed. To eliminate any particles larger than $4.75 \mathrm{~mm}$, the sand was first sieved using a $4.75 \mathrm{~mm}$ sieve. The fineness modulus of the used sand was found to be 2.75 . The properties of fine aggregates are listed in Table (2).

Table (2)

$$
\text { properties of fine aggregates. }
$$

\begin{tabular}{l||c}
\multicolumn{1}{c|}{ Property } & Test Result \\
\hline Specific gravity & 2.61 \\
\hline Volumetric weight $(\mathrm{t} / \mathrm{m} 3)$ & 1.75 \\
\hline Void ratio & $35 \%$ \\
\hline Fineness modulus & 2.75 \\
\hline Clay, silt, and fine dust (by weight) & $1.85 \%$ \\
\hline Chloride \% (by weight) & 0.02
\end{tabular}

\subsection{Coarse Aggregates}

Crushed graded hard Dolomite (locally available) was used in the concrete mix throughout the experimental study. Two types of Dolomites were used in the concrete mix. The first type (number 1) has a maximum size of 3/4" (19 mm) for specimens, while the second type (number 0 ) has a maximum size of $3 / 8$ " $(10 \mathrm{~mm})$ for the strengthening layers. The general shape was angular and sub-angular, the surface texture was rough, uniform, and free from any undesired impurities. The physical properties of the crushed dolomite (i.e., coarse aggregates) are listed in Table (3).

TABLE (3)

THE PROPERTIES OF COARSE AGGREGATE.

\begin{tabular}{|c|c|c|}
\hline \multirow{2}{*}{ Property } & \multicolumn{2}{|c|}{ Test Result } \\
\hline & Dolomite no (1) & Dolomite no (0) \\
\hline type & \multicolumn{2}{|c|}{ crushed } \\
\hline Specific gravity & 2.63 & 2.55 \\
\hline Volumetric weight $(\mathrm{t} / \mathrm{m} 3)$ & 1.50 & 1.53 \\
\hline Total water absorption & $1.6 \%$ & $1.6 \%$ \\
\hline Fineness modulus & 6.90 & 5.30 \\
\hline
\end{tabular}




\subsection{Cement}

Ordinary Portland cement used in all experimental work was provided from the Suez factory. The cement was of uniform color and free from any hard lumps. The usual chemical and physical properties are following the Egyptian Standard Specification ESS 373/2007. Table (4) presents the properties of the used Portland cement.

TABLE (4)

PHYSICAL PROPERTIES OF ORDINARY PORTLAND CEMENT

\begin{tabular}{|c|c|c|}
\hline Test Description & $\begin{array}{c}\text { ESS } 373 \text { / } 2007 \\
\text { Specification Limits }\end{array}$ & $\begin{array}{c}\text { Test } \\
\text { Results }\end{array}$ \\
\hline $\begin{array}{l}\text { Fineness of cement percentage } \\
\text { retained on the standard } \\
0.09 \mathrm{~mm} \text { sieve by weight }\end{array}$ & maximum $10 \%$ & $6.8 \%$ \\
\hline $\begin{array}{l}\text { Soundness of cement } \\
\text { (Le Chatelier test) }\end{array}$ & maximum $10 \mathrm{~mm}$ & $3.5 \mathrm{~mm}$ \\
\hline $\begin{array}{l}\text { Percentage of water to give a } \\
\text { paste of standard consistency, } \\
w / c \%\end{array}$ & - & $30 \%$ \\
\hline $\begin{array}{l}\text { Setting Time (Vicat test) } \\
\text { Initial } \\
\text { Final }\end{array}$ & $\begin{array}{l}\text { minimum } 45 \mathrm{~min} . \\
\text { maximum } 10 \mathrm{hr}\end{array}$ & $\begin{array}{l}\text { hr.: min. } \\
1: 45 \\
6: 50\end{array}$ \\
\hline $\begin{array}{l}\text { Compressive strength of } \\
\text { mortar } 7 \times 7 \mathrm{~cm} \text { cubes } \\
\text { after } 3 \text { days } \\
\text { after } 7 \text { days }\end{array}$ & $\begin{array}{l}\text { minimum } \\
160 \mathrm{Kg} / \mathrm{cm}^{2} \\
\text { minimum } \\
240 \mathrm{Kg} / \mathrm{cm}^{2}\end{array}$ & $\begin{array}{l}205 \\
280\end{array}$ \\
\hline
\end{tabular}

\subsection{Water}

For mixing and curing the examined specimens, clean drinkable fresh water free of contaminants was used. The water was free from impurities, organic matter, silt, oil, sugar, acidic material.

\subsection{Steel Reinforcement}

High tensile steel bars with $20 \mathrm{~mm}$ diameter were used as dowel bars for tested slabs in the first group. Tests were performed to evaluate yield stress, ultimate strength and elongation for the steel used. The results are given in Table (5).

TABLE (5)

\begin{tabular}{|c|c|c|c|c|c|c|}
\hline \multirow[b]{2}{*}{$\begin{array}{c}\text { diameter } \\
(\mathbf{m m})\end{array}$} & \multicolumn{6}{|c|}{ PROPERTIES OF STEEL REINFORCEMENT } \\
\hline & Grade & $\begin{array}{c}\text { Actual } \\
\text { area } \\
\mathbf{c m}^{2}\end{array}$ & $\begin{array}{c}\text { Unit } \\
\text { weight } \\
\mathrm{Kg} / \mathrm{m}\end{array}$ & $\begin{array}{c}\text { Yield } \\
\text { strength } \\
\mathrm{Kg} / \mathrm{cm}^{2}\end{array}$ & $\begin{array}{l}\text { Ultimate } \\
\text { strength } \\
\mathrm{Kg} / \mathrm{cm}^{2}\end{array}$ & م. \\
\hline$\Phi 20$ & $36 / 52$ & 3.14 & 2.47 & 5440 & 6285 & $\begin{array}{l}25 . \\
83\end{array}$ \\
\hline
\end{tabular}

\subsection{Glass fiber reinforced polymers bars (GFRP)}

The pultrusion method was utilized to make the GFRP dowel bars used in this investigation. Pultrusion of continuous ECR-glass filament with vinyl ester resin is used. This resin matrix has excellent resistance against corrosion, alkaline attack, acid, and solvent resistance (Brbero 1999) [29], all of which are essential factors in the dowel bars' long life. The glass fibers are arranged in a unidirectional way, parallel with the longitudinal direction. In Table (6), the mechanical characteristics of the GFRP bars are presented as supplied by the manufacturer.

GFRP bars are locally fabricated in a private factory at 10th of Ramadan city, in which polyester is injected with braided strands, followed by a separate performing system, and then dragged through a heated stationary die where the polyester is polymerized. The reinforcement is impregnated by dragging it through a bath and then the polyester saturated reinforcement exits the die in a solid-state. The produced GFRP bars are shown in Fig. (3). the mechanical properties of the GFRP dowel bars are presented in Table (6), as supplied by the manufacturer.

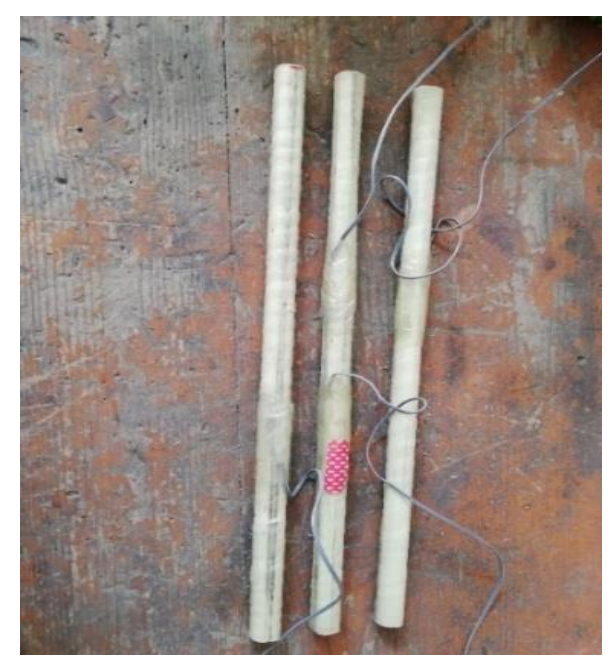

Fig. (3): GFRP bars.

Shear is the most common mechanism for load transfer by dowels at the JPCP's transverse joints. In the longitudinal direction, GFRP dowels have a greater strength and stiffness (parallel with the direction of fibers). In the longitudinal direction, GFRP dowels have a higher tensile strength than steel bars, but their transverse characteristics are significantly weaker. When utilizing GFRP as a dowel bar, its shear strength is critical, considering the weakness of GFRP in the transverse direction.

TABLE (6)

PROPERTIES OF GFRP BARS, ACCORDING TO THE MANUFACTURER.

\begin{tabular}{l||c}
\multicolumn{1}{c||}{ Property } & Values \\
\hline Diameter of bars & $20 \mathrm{~mm}$ \\
\hline Area of bars & $3.14 \mathrm{~cm}^{2}$ \\
\hline No. of strands & 130 \\
\hline Area of fibers & $1.26 \mathrm{~cm}^{2}$ \\
\hline Fiber ratio by area & $40 \%$ \\
\hline Tensile strength of fibers & $13800 \mathrm{~kg} / \mathrm{cm}^{2}$ \\
\hline Modulus of elasticity of fibers & $900000 \mathrm{~kg} / \mathrm{cm}^{2}$ \\
\hline Permissible shear stress of bar & $3106 \mathrm{~kg} / \mathrm{cm}^{2}$ \\
\hline Strain at failure & $15000 \times 10-6$ \\
\hline \multicolumn{1}{c|}{ Surface condition } & Smooth surface
\end{tabular}

\section{EXPERIMENAL PROGRAM}

\subsection{Tested specimens.}

In this paper, test specimens were fabricated to investigate and assess whether GFRP dowel bars are a good alternative to steel dowel bars, through a set of conditions and parameters. Eight specimens were cast and tested to investigate the loaddeflection response of JPCP using the different types of dowel bars. The tested specimens were models of a typical prototype JPCP with a length of $1000 \mathrm{~mm}$ in both directions and $200 \mathrm{~mm}$ thickness, as shown in Fig (4). For all the tested specimen's 
strain of dowel bars, cracking load and ultimate load were recorded.

The assumptions on the size of the slab, base layers, and dowels diameters were established based on a variety of criteria, including:

First, the slab dimensions of $1000 \times 1000 \mathrm{~mm}$ were one of the greatest recommended dimensions that we can manage by moving it from the location where it was casting on the floor to the top of the tank filled with three layers of subbase in the loading frame.

Second, the slab's thickness is $200 \mathrm{~mm}$. This thickness was chosen based on the diameters of the dowels available for testing. Therefore, we considered sample dimensions that were comparable to those in some previous studies, including AlHumeidawi et al. (2014) [12] in which specimens were used that were very similar in size to our specimens, which were $900 \times 900 \times 200 \mathrm{~mm}$. In general, the sample dimensions were acceptable for the frame and tank capabilities in the laboratory.

Third, the subbase layers have a thickness of $75 \mathrm{~cm}$. This thickness was chosen based on the clearance available in the frame.
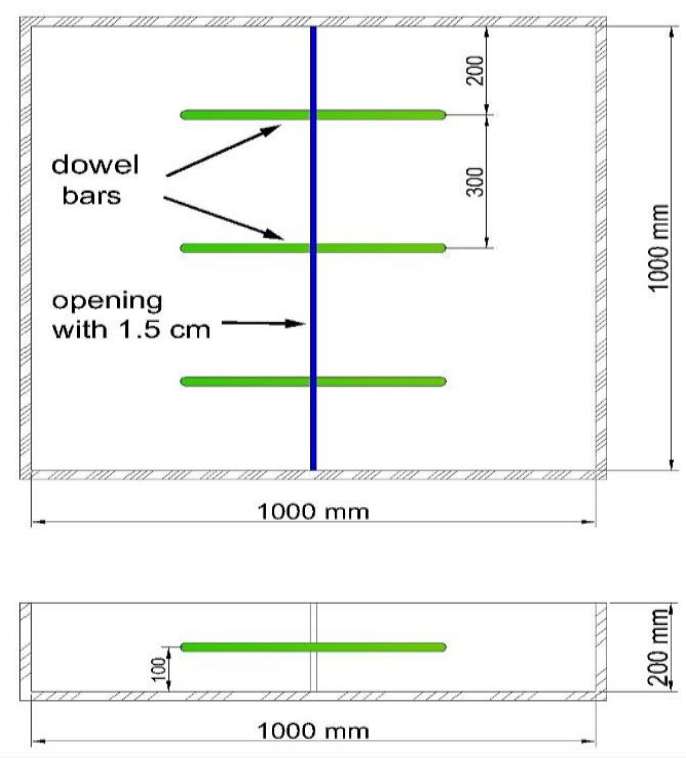

a) Sketch for the mold with dowels and sectional view for the mold.

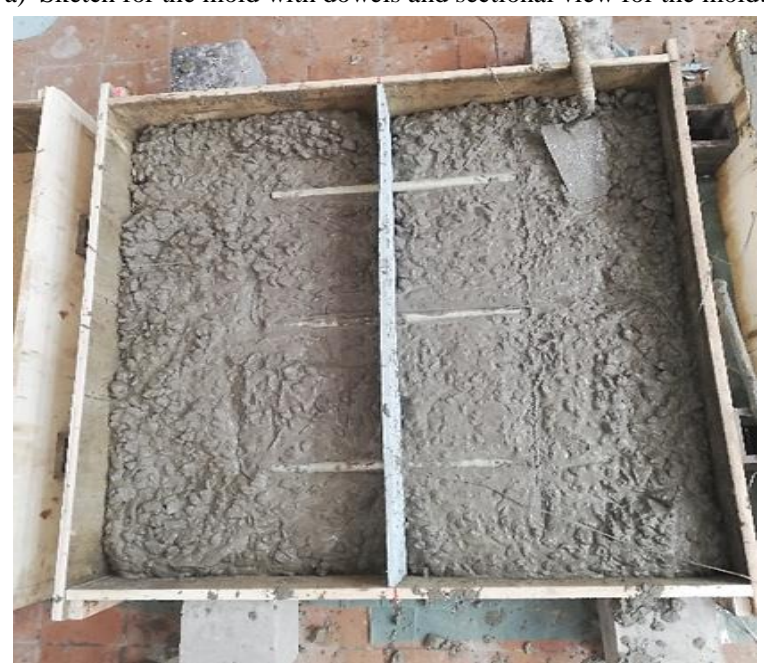

b) Complete mold with dowels.

Fig. (4): Specimen with three dowel bars.

\subsection{Design of Test Program}

The parameters of the test program and the symbols will be used to describe the conditions of specimens were the followin: 1 -The material of dowel bars:
a) steel dowel bar (S).
b) (GFRP) dowel bar (G).

2 -The misalignment method:
a) None (N).
b) Horizontal $(\mathrm{H})$.
c) Vertical (V).
d) Aligned (A).

The eight (JPCP) tested specimens were divided into two main groups, as shown in table (7).

\subsection{Concrete making and curing.}

\subsubsection{Concrete making}

Before placing, the specimen molds were tightly assembled and checked for dimensional accuracy and well cleaned. A 120liter mixer with a speed of approximately $50 \mathrm{rpm}$ was used. In the mixer drum, coarse aggregate, sand, and cement were added in the following order: coarse aggregate, sand, and cement. For one minute, the dry ingredients were mixed without the addition of water. The water was then added. Three minutes were added to the procedure to guarantee proper mixing. Before casting, the forms were coated with a thin coating of oil so that the specimens can be easily removed from the mold after 24 hours. The required cover was ensured by using cement mortar spacers placed between steel and mold. All sixteen specimens were cast using the same concrete mix. Pouring concrete in the formwork took place immediately after mixing. After filling the molds, the concrete was manually compacting by using a metal rod measuring $1.6 \mathrm{~cm}$ in diameter and $45 \mathrm{~cm}$ in length, as shown in Fig (5). Then, the excess concrete at the top of the mold was struck off with a straight edge and the top surface was finished smooth by trawling, as shown in Fig (6).

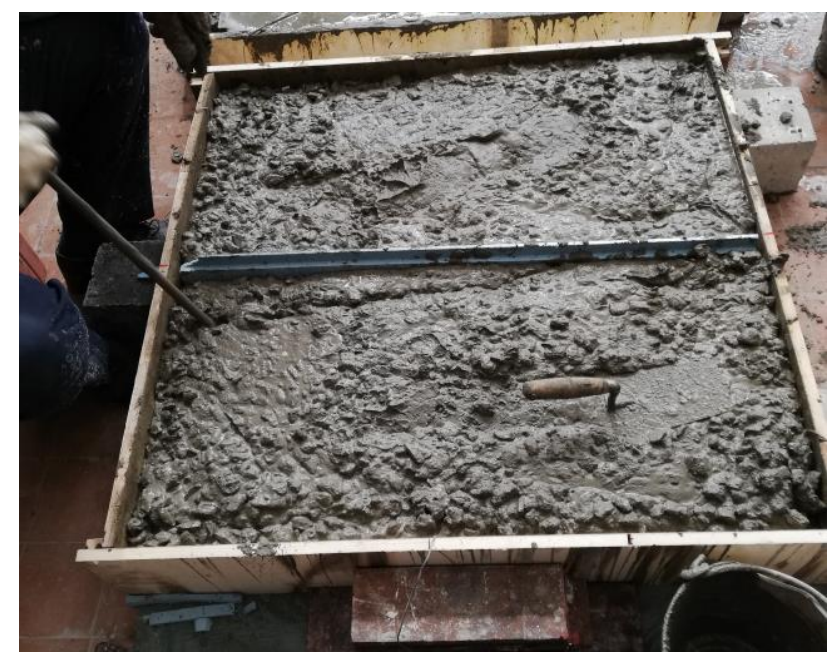

Fig. (5): Manually Compacting of the concrete specimen. 


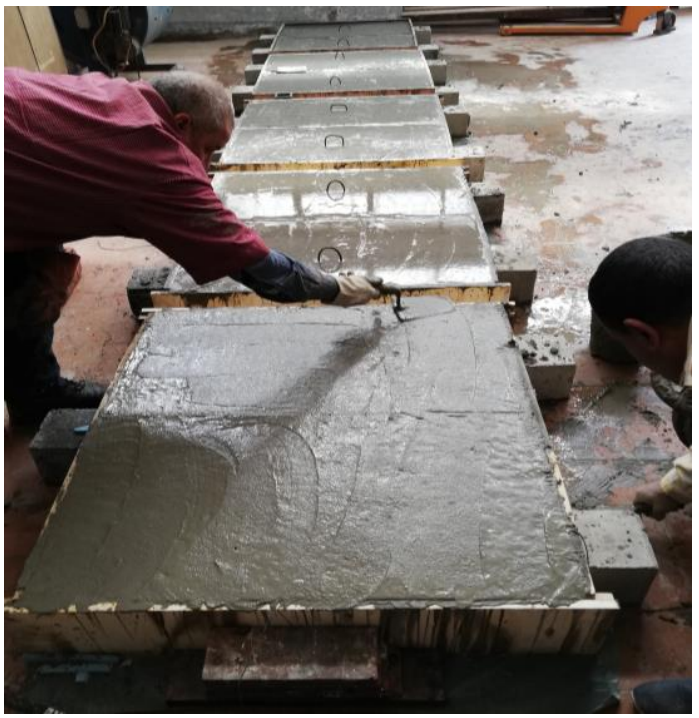

Fig. (6): Surface finishing of the concrete specimen.

\subsubsection{Curing}

The specimens were left in the forms for 24 hours. After that, the sides of the forms were stripped away. The specimens were cured by water sprinkling twice a day for 14 days. After the curing period, the specimens were left in the lab atmosphere until the testing date.

\subsubsection{Compression test for quality control}

Standard cubes of $150 \times 150 \times 150 \mathrm{~mm}$ were tested in compression at the same date of the testing as the tested pushout specimen. The test was carried out in a compression-testing machine of capacity $2000 \mathrm{kN}$.

TABLE (7)

THE EXPERIMENTAL TEST PROGRAM.

\begin{tabular}{|c|c|c|c|c|c|c|}
\hline $\begin{array}{r}\text { Group } \\
\text { No. }\end{array}$ & $\begin{array}{c}\text { Subgroup } \\
\text { No. }\end{array}$ & $\begin{array}{l}\text { Code of } \\
\text { Specimen }\end{array}$ & $\begin{array}{l}\text { Dowel } \\
\text { bars dimeter }\end{array}$ & $\begin{array}{l}\text { Material } \\
\text { of Dowel }\end{array}$ & $\begin{array}{l}\text { Misalignment } \\
\text { method }\end{array}$ & $\begin{array}{l}\text { Length of } \\
\text { dowel bars }\end{array}$ \\
\hline \multirow{4}{*}{$\begin{array}{l}\text { First } \\
\text { group }\end{array}$} & control & S16N45 & $3 \otimes 20$ & STEEL & NONE & $45 \mathrm{~cm}$ \\
\hline & \multirow{3}{*}{$1-\mathrm{a}$} & S20V45 & $3 \otimes 20$ & STEEL & VERTICAL & $45 \mathrm{~cm}$ \\
\hline & & S20H45 & $3 \otimes 20$ & STEEL & HORIZONTAL & $45 \mathrm{~cm}$ \\
\hline & & S20A45 & $3 \otimes 20$ & STEEL & ALIGNED & $45 \mathrm{~cm}$ \\
\hline \multirow{4}{*}{$\begin{array}{l}\text { second } \\
\text { group }\end{array}$} & control & G16N45 & $3 \otimes 20$ & GFRP & NONE & $45 \mathrm{~cm}$ \\
\hline & \multirow{3}{*}{$2-\mathrm{a}$} & G20V45 & $3 \otimes 20$ & GFRP & VERTICAL & $45 \mathrm{~cm}$ \\
\hline & & G20H45 & $3 \otimes 20$ & GFRP & HORIZONTAL & $45 \mathrm{~cm}$ \\
\hline & & G20A45 & $3 \otimes 20$ & GFRP & ALIGNED & $45 \mathrm{~cm}$ \\
\hline
\end{tabular}

\section{First Group}

The first group contains four specimens that were divided into a control specimen and one subgroup (1-a) adding to one a reference specimen with the standard specifications without any change and was called the control specimen. The main element common to all specimens of this group is that the material made of dowel bar is steel. The control specimen with code (S20N45). It is the standard specimen without any changes related to the study variables, where the length of the dowel bar is the standard length $(45 \mathrm{~cm})$ and none misalignment method, as shown in fig (8).

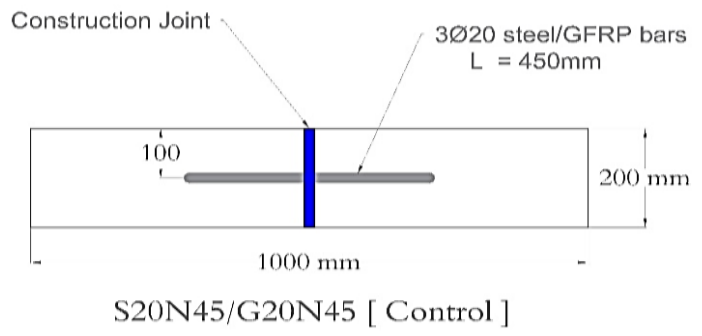

Fig.(8): The control specimens of first / second groups.
An explanation of the code used, for example (S20N450):

- $1^{\text {st }}$ letter (S) shows the type of material the dowel bar is made of.

- $1^{\text {st }}$ number (20) shows the diameter of dowel bar in mm.

- $2^{\text {nd }}$ letter $(\mathrm{N})$ shows the type of misalignment method.

- $2^{\text {nd }}$ number (45) shows the length of dowel bar in $\mathrm{cm}$.

\section{Subgroup (1-a)}

This subgroup contains three specimens (S20H45, S20V45 $\&$ S20A45). This group studies the variable for the type of misalignment method of dowel bars, where the first specimen (S2OH45) has the horizontal type of misalignment method. The horizontal misalignment method is a statement that the first dowel bar has a right horizontal displacement of $5 \mathrm{~cm}$ from the centerline of the specimen. The next dowel has a left horizontal displacement of $5 \mathrm{~cm}$ from the centerline of the specimen without any vertical displacement, and so on.

The second specimen (S20V45) with the vertical type of misalignment method. The vertical misalignment method is a statement that the first dowel bar has an upward vertical displacement of $3 \mathrm{~cm}$ from the centerline of the specimen, and 
the next dowel bar has a downward vertical displacement of 3 $\mathrm{cm}$ from the centerline of the specimen, and so on.

The third specimen (S20A45) with the aligned type of misalignment method. The aligned misalignment method is a statement that the first dowel bar has tilted at an angle of 12.75 degrees, while the second dowel bar has tilted at the same angle, but in the opposite direction, and so on.

All these specimens were in comparison with the control specimen (S20N45) which with none misalignment method, as shown in fig (9).
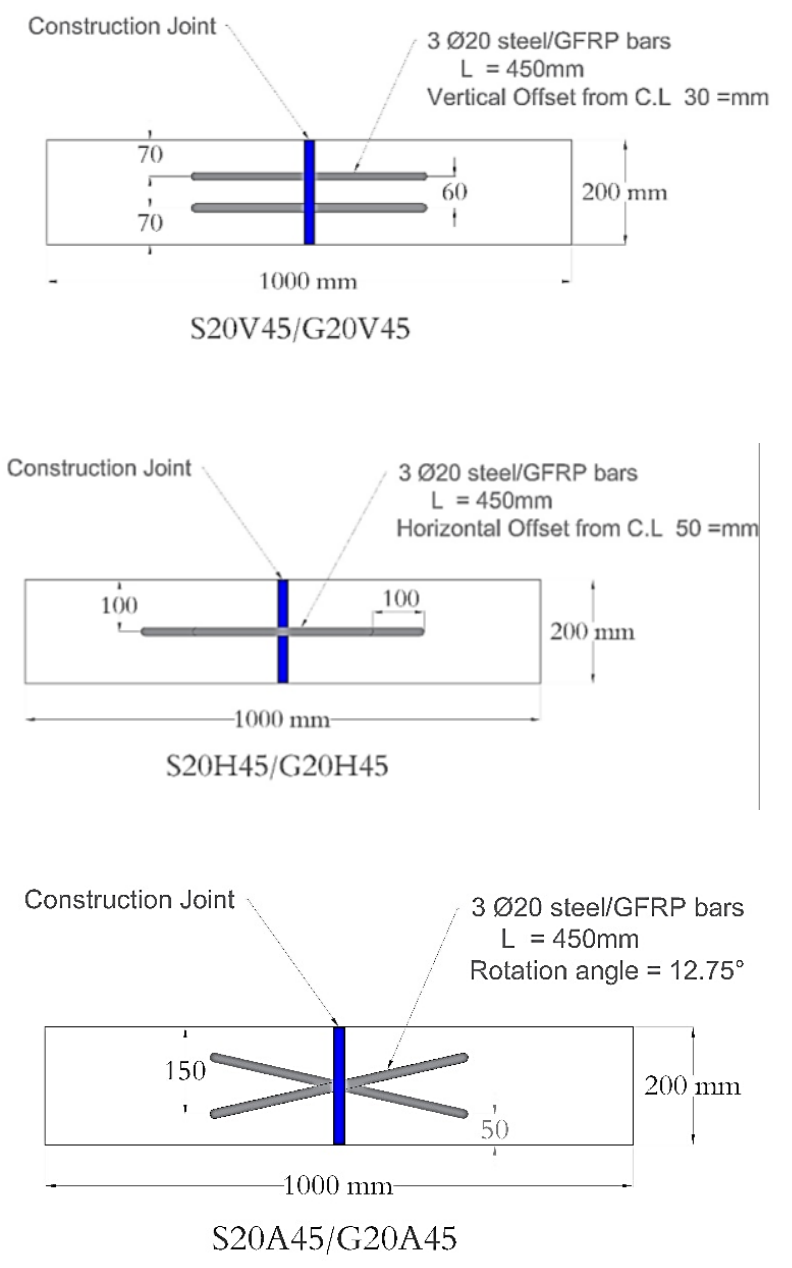

Fig (9): The specimens of subgroups (1-a)/(2-a).

\section{Second Group}

The second group contains four specimens that were divided into a control specimen and one subgroup (1-a) adding to one a reference specimen with the standard specifications without any change and was called the control specimen. The main element common to all specimens of this group is that the material made of dowel bar is GFRP. The control specimen with code (G20N45). It is a standard specimen without any changes related to the study variables, where the length of the dowel bar is the standard length $(45 \mathrm{~cm})$ and none misalignment method, as shown in fig (8).

\section{Subgroup (2-a)}

This subgroup contains three specimens (G20H45, G20V45, and G20A45). This group studies the variable for the type of misalignment method of dowel bars, where the first specimen (G20H45) has the horizontal type of misalignment method. The second specimen (G20V45) with the vertical type of misalignment method. The third specimen (G20A45) with the aligned type of misalignment method. All these specimens were in comparison with the control specimen (G20N45) with none misalignment method, as shown in fig (9).

\subsection{Test setup and testing procedures.}

The test set-up used in this study consisted of rigid steel frames supported on the laboratory rigid floor, as shown in Fig. (10).

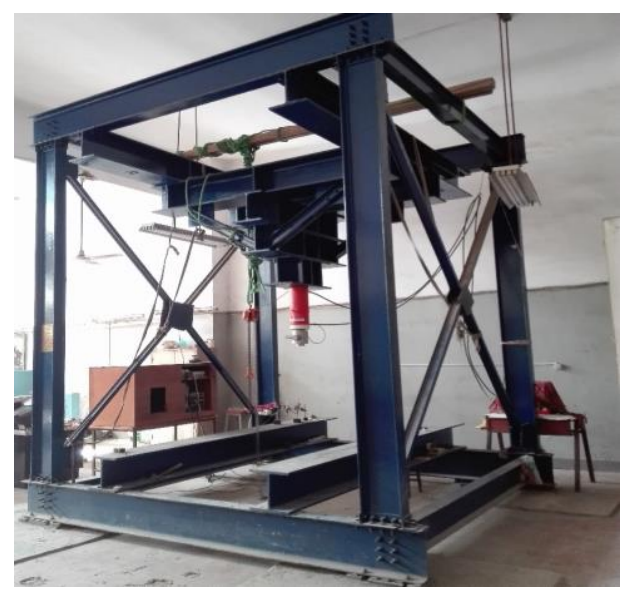

Fig. (10): The rigid system of reaction steel frame.

\subsubsection{Test setup}

The load was applied using a hydraulic jack of 100-ton capacity connected to an electrical pump that provides oil pressure. The load was applied and measured using a load cell connected to a data acquisition system. The readings were recorded and saved in an excel sheet on computer. The specimens were prepared for testing by resting on soil in a steel container with dimensions of $1500 \times 1500 \times 750 \mathrm{~mm}$. This soil was compacted by a hummer weighing $10 \mathrm{~kg}$ at a three-layer depth of $250 \mathrm{~mm}$. These soil layers' act as a subbase course layers under the pavement concrete slabs, as shown in Fig. (11).

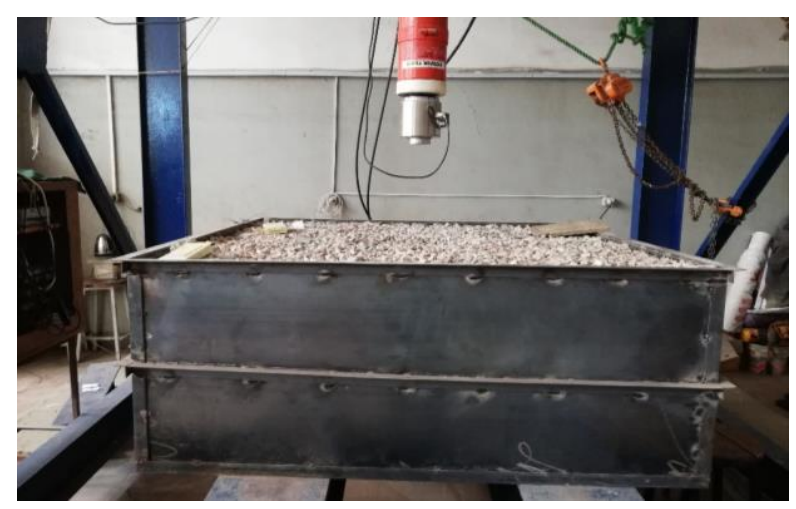

Fig. (11): The steel container filled with subbase layers. 
The specimens were placed over the subbase layers in the middle of the container then, the load was applied using a hydraulic jack on a steel plate with dimensions of $300 \times 300 \times 50$ $\mathrm{mm}$ to ensuring that the load is distributed over an area greater than the area of the load cell, which has a diameter of $100 \mathrm{~mm}$ to avoid penetration of the specimens, as shown in Fig. (12).

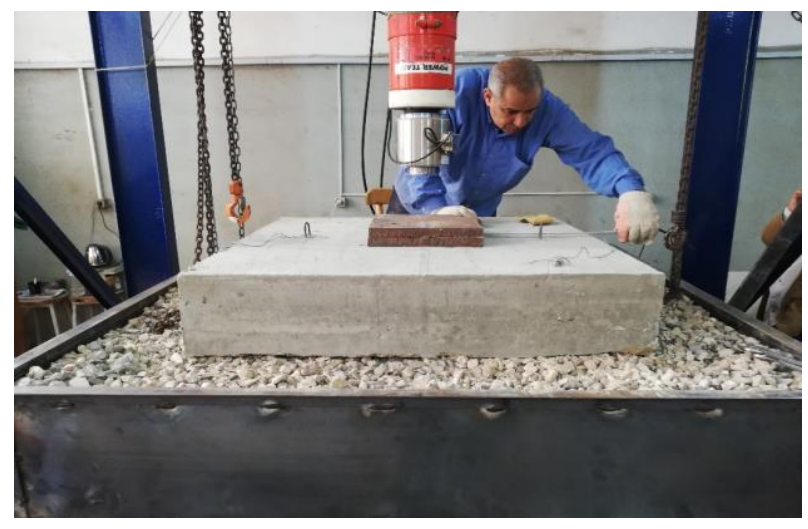

Fig. (12): The specimen was placed in the middle of container and the steel plate was placed in its center.

For each dial gauge, a unique arrangement was designed to ensure that it remained in its exact location and to ensure proper readings. Propagation of cracks was marked after each load increment up to failure. Two strain gauges were installed in the middle of the dowel bar at $50 \mathrm{~mm}$ to the right and left of the transverse joint and named them BR and BL. The first letter indicates the order of the dowel bar, and the second letter indicates the location of the strain gauge right or left of the transverse joint. One strain gauge was installed in the first dowel bar at $50 \mathrm{~mm}$ to the left side of the transverse joint and named it AL. The last strain gauge was installed in the last dowel bar at $50 \mathrm{~mm}$ to the right side of the transverse joint and named it CR, as shown in Fig. (13).

The strain gauges are fixed on the dowel bar as follows, the surface of the dowel is sanded and smoothed, and then the strain gauges are glued to it. It was covered in a roll of colorless tape to protect it from concrete. For each specimen, new 4 strain gauges were fixed.

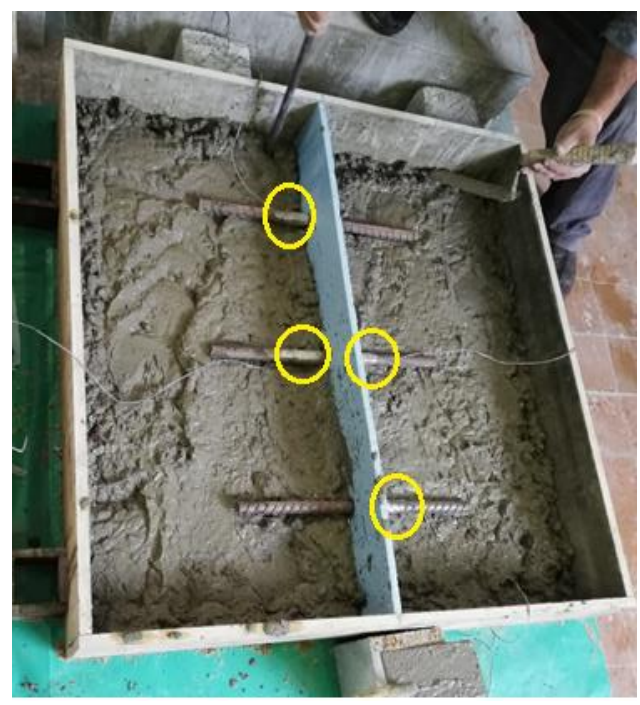

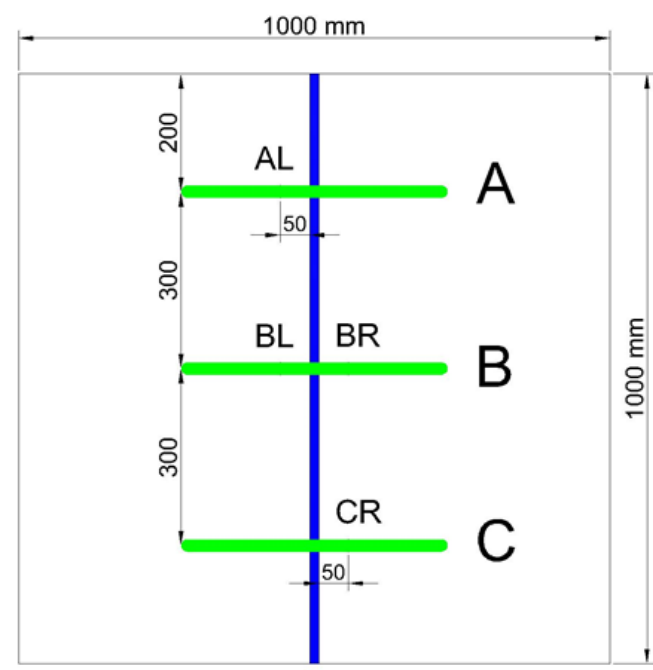

Fig. (13): Arrangements of strain dial gauges.

In total, 4 strain gauges were installed in each specimen, one in the first dowel bar, two in the second dowel bar, and one in the last dowel bar. These strain gauges were used to measure the strain in the steel and FRP bars during loading.

\section{The properties of the strain gauge were as follows:}

Gauge length: $6 \mathrm{~mm}$.

Gauge factor: $2.12 \pm 1 \%$.

Gauge resistance: $120.3 \pm 0.5 \Omega$.

Transverse sensitivity: $0.1 \%$.

\subsection{Test Procedures}

For each test, the specimen was aligned inside the testing frame and the instrumentations (strain gauges) were connected to the data acquisition system. The data acquisition system starts to gather data before the application of load. The load was applied at a point in the vertical direction and was increased monotonically using an electric hydraulic jack of $1000 \mathrm{kN}$ capacity until failure of the specimen. The specimen was observed to follow the propagation of cracks. The load was applied in a regular interval $(10 \mathrm{kN})$ before the formation of the first crack. After the formation of the first crack, the load was applied in a regular interval $(5 \mathrm{kN})$, according to the specifications and capabilities available for the load cell of the loading frame in the laboratory. The load was kept constant while cracks were marked. During the test, the initiation and propagation of cracks were marked after each load increment up to failure to understand the behavior of the tested specimens. Cracking loads, ultimate failure load and strain were recorded simultaneously.

\section{EXPERIMENTAL RESULTS AND DISCUSSION}

Presents and discusses the experimental results of eight JPCP specimens evaluated as a rested-on soil in a steel container with dimensions of $1500 \times 1500 \times 750 \mathrm{~mm}$. The 
concrete size, concrete compressive strength, operating circumstances, casting, and compaction were identical for all specimens. The initial cracking load, ultimate load and strain values for steel reinforcement and GFRP dowel bars were measured. The effect of the key parameters considered in this study was shown by comparing the findings for all specimens.

Generally, similar behavior was observed in all tested specimens under loading. Firstly, when evaluating the influence of dowel misalignment, the current set of experimental results took into account adequate foundation stiffness. Second, GFRP dowels were compared to steel dowels to see if they could lower the needed pull-out load. Finally, the combined impact of dowel misalignment and dowel materials.

\subsection{Cracking load and Ultimate load}

For all tested specimens, the ultimate load capacity of each JPCP specimen was determined by the peak load attained during the loading test. The cracking load was a load that caused tensile stress in a structural concrete element exceed the tensile strength of the concrete, as a result, cracks began to appear, as shown in table. (8)

TABLE (8)

\begin{tabular}{|c|c|c|c|c|c|}
\hline \multicolumn{6}{|c|}{ EXPERIMENTAL TEST RESULTS } \\
\hline Main Group & Subgroup & Specimen name & $\begin{array}{l}\text { Cracking load } \\
\operatorname{Pcr}(\mathbf{k N})\end{array}$ & $\begin{array}{l}\text { Ultimate load } \\
\text { Pu }(k N)\end{array}$ & $\begin{array}{l}\text { Average strain in } \\
\text { dowel bars }(u m / m)\end{array}$ \\
\hline \multirow{4}{*}{ Group one } & Control & S20N45 & 143 & 293.2 & 771.8 \\
\hline & \multirow{3}{*}{$1-\mathrm{a}$} & S20V45 & 152 & 334.9 & 887.9 \\
\hline & & $\mathrm{S} 20 \mathrm{H} 45$ & 176 & 424.5 & 1021.1 \\
\hline & & S20A45 & 163 & 380.8 & 930.6 \\
\hline \multirow{4}{*}{ Group two } & Control & G20N45 & 161 & 390.5 & 780.7 \\
\hline & \multirow{3}{*}{$2-\mathrm{a}$} & G20V45 & 179 & 422 & 965.5 \\
\hline & & $\mathrm{G} 20 \mathrm{H} 45$ & 192 & 512.9 & 1185.7 \\
\hline & & G20A45 & 183 & 487.6 & 1066.7 \\
\hline
\end{tabular}

\section{First group}

Fig. (14) Shows the required loads for cracks appearing in the tested specimens for the various instances of steel bar dowel misalignment. The general observations obtained from this figure showed that any dowel misalignment produced an increase in the cracking load. In addition, the initial cracks of the non-misalignment method started at a lower load compared with the other methods, and its value was $143 \mathrm{kN}$. The horizontal misalignment method appeared to be the best because the cracking load value was the highest compared to the other methods at $176 \mathrm{kN}$, followed by the aligned method at $163 \mathrm{kN}$, and finally the vertical method at $152 \mathrm{kN}$. This means that the specimens S20H45, S20A45 and S20V45 achieved an increase in the cracking load by about $123.07 \%$, $113.98 \%$ and $106.29 \%$, respectively, compared with that of the control specimen.

Fig. (15) Shows the required loads for the tested specimens to collapse for various instances of dowel misalignment for steel dowel bars. The general observations obtained from this figure showed that any dowel misalignment produced an increase in the ultimate load. In addition, the control specimen with no misalignment was the first to collapse at a lower load compared with the other methods, and its value is $293.2 \mathrm{kN}$. The horizontal misalignment method appeared to be the best because the ultimate load value was the highest compared with the other methods at $424.5 \mathrm{kN}$, followed by the aligned method at $380.8 \mathrm{kN}$, and finally the vertical method at $337.9 \mathrm{kN}$. This means that the specimens S20H45, S20A45 and S20V45 achieved an increase in the ultimate load by about $144.63 \%$, $129.87 \%$ and $115.24 \%$, respectively, compared with that of the control specimen.

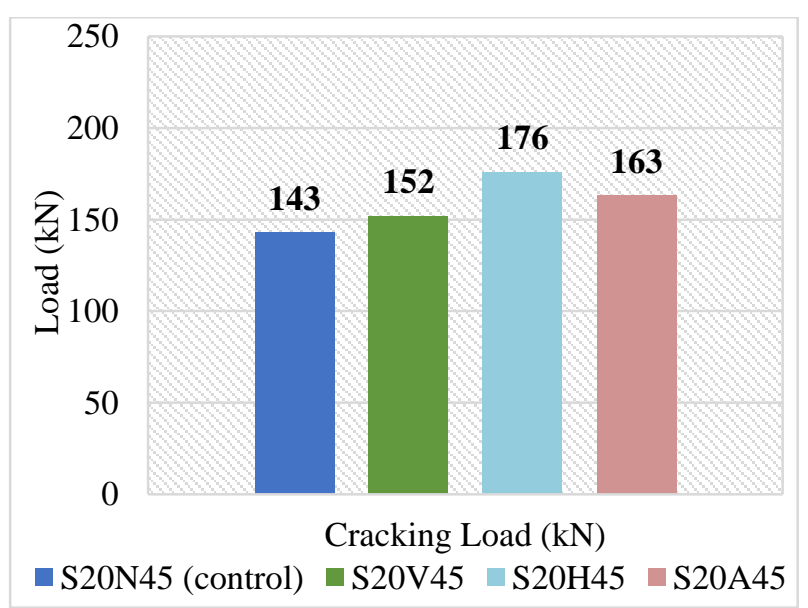

Fig. (14): Comparison between the cracking loads for all specimens in first group. 


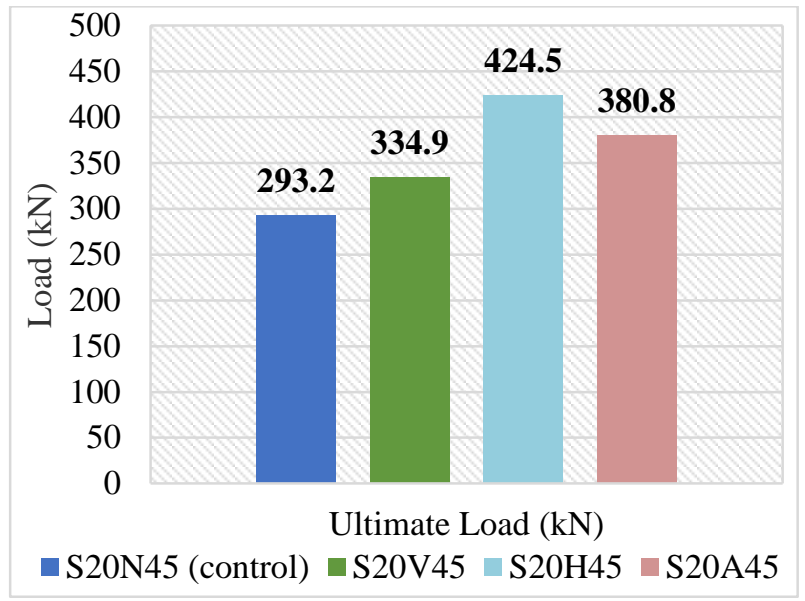

Fig. (15): Comparison between the ultimate loads for all specimens in first group.

\section{Second group}

Generally, similar behavior was observed in all tested specimens of the two groups under loading with various load values. It also appeared from the fig. (16) that the fastest specimen that has cracked was the control specimen of the second group GFRP dowel bars with no misalignment method compared with the other methods, and its value was $161 \mathrm{kN}$. The horizontal misalignment method appeared to be the best because the cracking load value was the highest compared with the other methods at $192 \mathrm{kN}$, followed by the aligned method at $183 \mathrm{kN}$, and finally the vertical method at $172 \mathrm{kN}$. This means that the specimens S20H45, S20A45 and S20V45 achieved an increase in the cracking load by about $119.25 \%$, $113.66 \%$ and $106.83 \%$, respectively, compared with that of the control specimen.

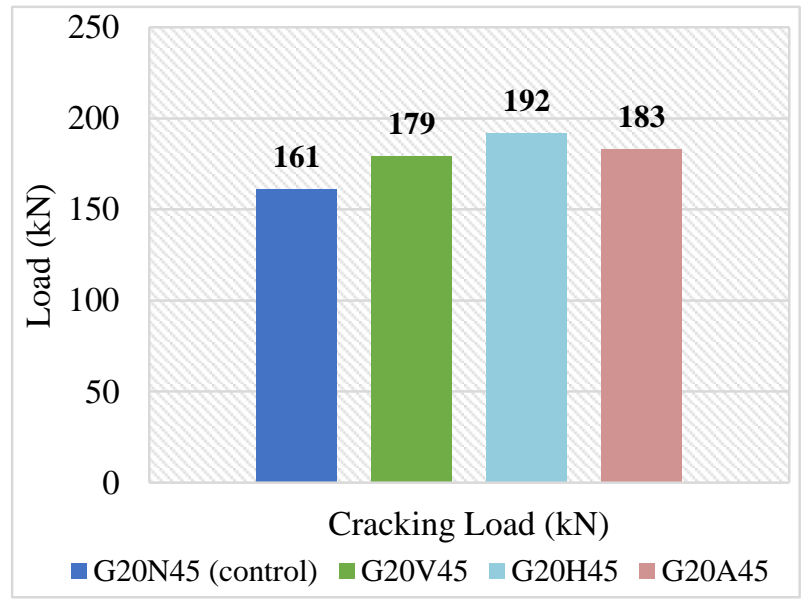

Fig. (16): Comparison between the cracking loads for all specimens in second group.

Fig. (17) Shows the required loads for the tested specimens to collapse for various instances of dowel misalignment for GFRP dowel bars. The general observations obtained from this figure showed that any dowel misalignment produced an increase in the ultimate load. In addition, the control specimen with no misalignment was the first to collapse at a lower load compared with the other methods, and its value was $390.5 \mathrm{kN}$. The horizontal misalignment method appeared to be the best because the ultimate load value was the highest compared with the other methods at $512.9 \mathrm{kN}$, followed by the aligned method at $487.6 \mathrm{kN}$, and finally the vertical method at $422.0 \mathrm{kN}$. This means that the specimens S20H45, S20A45 and S20V45 achieved an increase in the ultimate load by about $131.34 \%$, $124.86 \%$ and $108.06 \%$, respectively, compared with that of the control specimen.

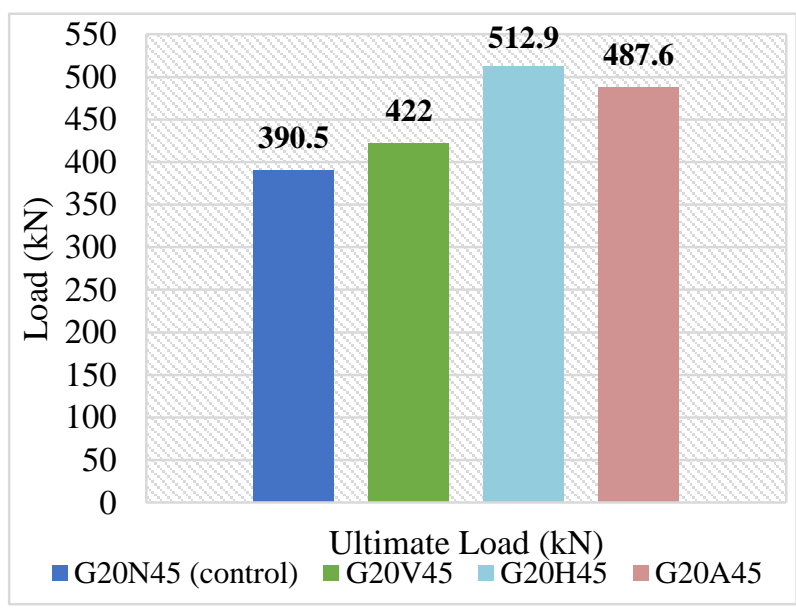

Fig. (17): Comparison between the ultimate load for all specimens in second group.

\subsection{Strain in reinforcement bars at failure}

For all tested specimens, the strain in dowel bars at the ultimate load capacity of each JPCP specimen was determined by four strain gauges that were installed in dowel bars during the loading test.

\section{First group}

The relationship between dowel bar strains and various misalignment methods (none - horizontal - vertical - aligned) for the tested specimens S20N45 (control specimen of the first group), S20H45, S20V45 and S20A45 is presented in Fig (18). Strains were $771.8 \mathrm{um} / \mathrm{m}, 1021.1 \mathrm{um} / \mathrm{m}, 930.6 \mathrm{um} / \mathrm{m}$, and 887.9 $\mathrm{um} / \mathrm{m}$ in dowel bars of specimens S20N45, S20H45, S20A45 and S20V45, respectively. This indicated that the strain values of S20H45, S20V45 and S20A45 specimens increased by about $132.30 \%, 120.57 \%$ and $115.04 \%$, respectively, compared with that of the control specimen. The order of dowel bars misalignment methods was descending in terms of value the dowel bar strains as follows: horizontal misalignment, aligned misalignment, vertical misalignment and the last is no misalignment method.

\section{Second group}

The relationship between dowel bar strains and different misalignment methods (none - horizontal - vertical - aligned) 
for the tested specimens G20N45 (control specimen of the second group), G20H45, G20V45 and G20A45 is presented in Fig (18). Strains were $780.7 \mathrm{um} / \mathrm{m}, 1185.7 \mathrm{um} / \mathrm{m}, 1066.7 \mathrm{um} / \mathrm{m}$ and $965.5 \mathrm{um} / \mathrm{m}$ in dowel bars of specimens G20N45, G20H45, G20A45 and GS20V45, respectively. This indicated that the strain values of $\mathrm{G} 20 \mathrm{H} 45, \mathrm{G} 20 \mathrm{~A} 45$ and G20V45 specimens increased by about $151.87 \%, 136.67 \%$ and $123.67 \%$, respectively, compared with that of the control specimen. The order of dowel bars misalignment methods was descending in terms of value the dowel bar strains as follows: horizontal misalignment, aligned misalignment, vertical misalignment and the last is no misalignment method.

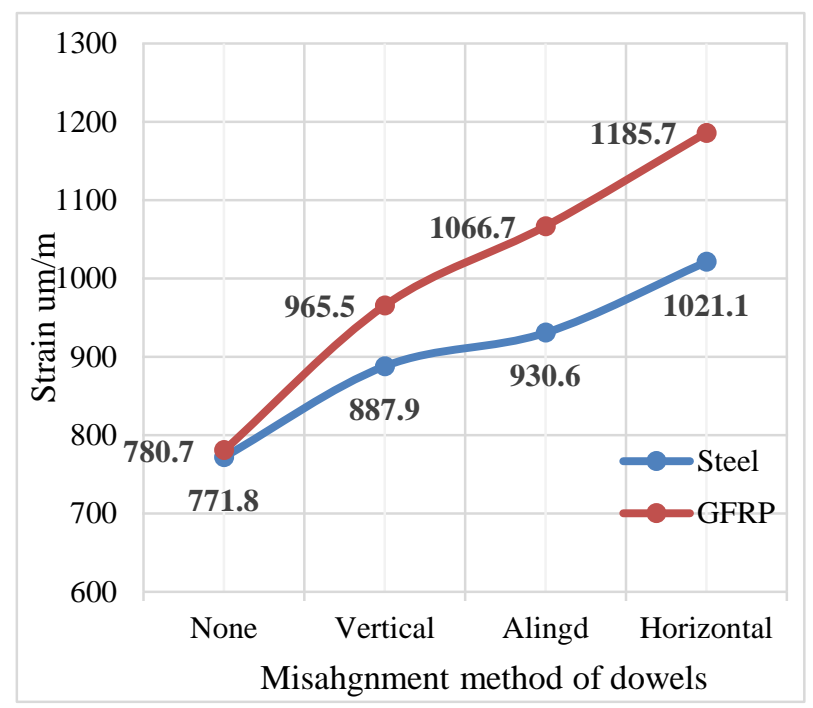

Fig.(18):Comparison between Strains in dowel bars and misalignment methods of steel / GFRP dowel bars.

\section{CONCLUSIONS}

Based on the results of this study, the following conclusions can be drawn:

1. In general, GFRP dowel bars provided greater ease of application that make the JPCP have a greater capacity to the resistance of loads.

2. The behavior of load-strain of steel dowel bars specimens was similar to GFRP dowel bars specimens. However, the behavior of steel dowel bars specimens was stiffer compared with GFRP dowel bars specimens.

3. The cracking load and ultimate load of GFRP dowel bars specimens increased by about $14 \%$ and $25 \%$, respectively, compared with that of steel dowel bars specimens.

4. The stain value of GFRP specimens increased by about $110 \%$ compared with that of steel dowel bars specimens.

5. The best method of misalignment of dowel bars in JPCP was the horizontal method. This method was listed in descending order based on the values of cracking and ultimate loads as follows: (horizontal - aligned - vertical none).
6. The misalignment methods were listed in descending order based on the values of dowel bars strain as follows: (horizontal - aligned - vertical - none). Where it was found that the horizontal method had value of dowel bar strain higher than the control specimens by about $51 \%$ in first group and higher by about $32 \%$ in second group.

\section{AUTHORS CONTRIBUTION}

\section{Mostafa M. Rabah,}

He provided the approval of the version to be published.

\section{Mohammed S. Eisa,}

He substantially contributed the conception or design of the work, data collection and tools, data analysis and interpretation, project administration, supervision, and final approval of the version to be published.

\section{Ahmed T. Elghanam,}

He determined the data collection and tools, data analysis and interpretation, funding acquisition, resources, methodology, drafting the article, and critical revision of the article.

\section{REFERENCES}

[1] Mancio, Mauricio, et al. "Evaluation of corrosion resistance of steel dowels used for concrete pavements." Journal of materials in civil engineering 20.10 (2008): 650-658 .

[2] Bian, Yi. Investigation of fiber reinforced polymer (FRP) dowel bars in rigid pavements. University of California, Davis, 2008.

[3] Porter, Max L., et al. Laboratory study of structural behavior of alternative dowel bars. No. DTFH61-01-X00042. 2006.

[4] Eddie, Darren, Ahmed Shalaby, and Sami Rizkalla. "Glass fiberreinforced polymer dowels for concrete pavements." ACI Structural Journal 98.2 (2001): 201-206.

[5] Porter, Max, and Nathan Pierson. "Laboratory evaluation of alternative dowel bars for use in Portland cement concrete pavement construction." Transportation research record 2040.1 (2007): 80-87 .

[6] Porter, Max L., et al. "Investigation of glass fiber composite dowel bars for highway pavement slabs.(2001)".

[7] AASHTO (1993). "AASHTO guide for design of pavement structure." American Association of State Highway and Transportation Officials Washington D. C.

[8] Friberg, B. F. "Design of dowels in transverse joints of concrete pavements." Transactions, American Society of Civil Engineers, 105(1940), 1076-1095.

[9] Finney, E. A. "Structural design considerations for pavement joints." Journal of the American Concrete Institute 28.1 (1956): 1-28.

[10] Timoshenko, S., and Lessells, J. M. (1925). Applied elasticity, Westinghouse technical night school press.

[11] Robert, M., Cousin, P., Ahmed, E., Montaigu, M., and Benmokrane, B. "Performance characteristics of GFRP dowels for concrete pavement." Annual Conference of Canadian society of civil engineering CSCE. Canada, (2010): 185-194.

[12] Al-Humeidawi, B. H., \& Mandal, P. (2018). Experimental investigation on the combined effect of dowel misalignment and cyclic wheel loading on dowel bar performance in JPCP. Engineering Structures, 174, 256266.

[13] ACI Committee, and International Organization for Standardization. Building code requirements for structural concrete (ACI 318-14), and American Concrete Institute, 2008.

[14] Agarwal, B. D., and L. J. Broutman. "Analysis and performance of fiber composites Second edition.(1990)".

[15] Teller LW, Cashell HD. Performance of doweled joints under repetitive loading. Public Roads 1958; 30:1-24. 
[16] Tayabji SD. Dowel placement tolerances for concrete pavements. Transp Res Rec 1986; 47-54.

[17] Khazanovich L, Buch N, Gotlif A. Evaluation of alignment tolerances for dowel bars and their effects on joint performance. Michigan: Michigan State University, Pavement Research Center of Excellence; 2001.

[18] Prabhu M, Buch N, Varma AH. Experimental investigation of effects of dowel misalignment on joint opening behavior in rigid pavements. Transport Res Rec 2006:15-27.

[19] Segner E, Cobb JR. A study of misaligned dowels in concrete pavements. State of Alabama, Highway Dept., Bureau of Research and Development (Montgomery); 1967.

[20] Prabhu M, Buch N, Varma AH. Experimental investigation of effects of dowel misalignment on joint opening behavior in rigid pavements. Transport Res Rec 2006:15-27.

[21] Prabhu M, Buch N, Varma AH. Analytical investigation of the effects of dowel misalignment on concrete pavement joint opening behaviour. Int $\mathrm{J}$ Pavement Eng 2009; 10:49-62.

[22] Prabhu M, Buch N, Varma AH. Experimental and analytical investigations of mechanistic effects of dowel misalignment in jointed concrete pavements. Transp Res Rec 2007; 2037:12-29.

[23] Hoegh K, Khazanovich L. Laboratory investigation of misaligned dowel behavior. J Test Eval 2009; 38:127-35.

[24] Saxena P, Hoegh K, Khazanovich L, Gotlif A. Laboratory and finite element evaluation of joint lockup. Transport Res Rec: J Transport Res Board 2009; 2095:34-42.

[25] Kim JK, Lee CS. Prediction of differential drying shrinkage in concrete. Cem Concr Res 1998; 28:985-94.

[26] Lim S, Jeong JH, Zollinger DG. Moisture profiles and shrinkage in earlyage concrete pavements. Int J Pavement Eng 2009; 10:29-38.

[27] Vijay PV, Hota VS, GangaRao Li H. Design and evaluation of jointed plain concrete pavement with fiber reinforced polymer dowels. Morgantown: West Virginia University; 2009.

[28] Silva, E. R. D., Balbo, J. T., \& Cargnin, A. P. (2021). Effects of dowel bars misalignment in jointed plain concrete pavements-A numerical analysis considering thermal differentials and bonded slab-base interface. Revista IBRACON de Estruturas e Materiais, 14 .

[29] Barbero, E. J. (1999). Introduction to composite materials design, Boca Raton, Fla

\section{Title Arabic:}

تأثير طريقة المحاذاة على أداء الأسياخ الوتدية في الفواصل العرضية للرصف

\section{Abstract Arabic:}

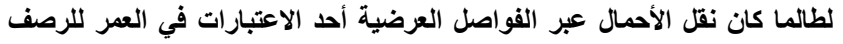

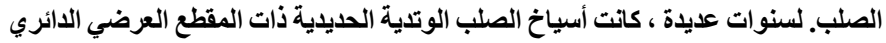

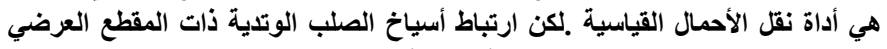

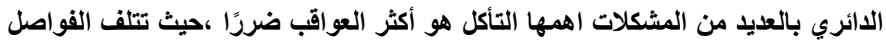

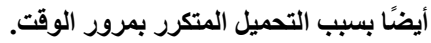
يقلم هذا البحث دراسة تجريبية في المقارنة بين الأسياخ الوتدية المبندة المصنعة من

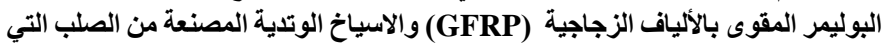

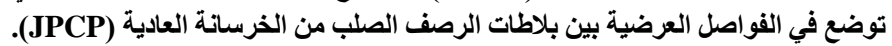

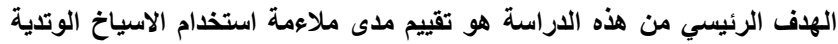

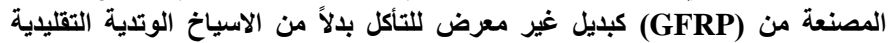

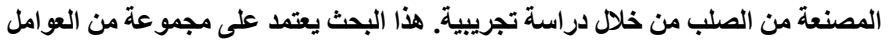

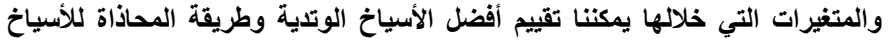
الوتدية عبر الفواصل العرضية. الخلاصة : كما هو متوقع ، فإن أسياخ (GFRP) يحسن من تحمل الفرلة البلاطات للأحمال

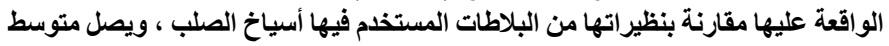

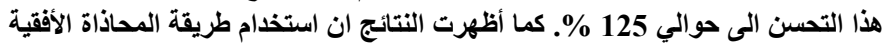

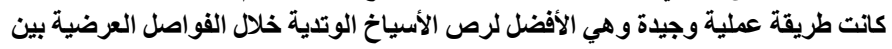

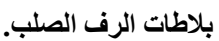

